\title{
The Use of Importance-Performance Analysis (IPA) in Evaluating Japan's E-government Services
} \section{Meng Seng Wong ${ }^{1}$, Nishimoto Hideki ${ }^{2}$ and Philip George ${ }^{3}$}

${ }^{1}$ Nottingham University, Business School, Malaysia, wong.mengseng@nottingham.edu.my

${ }^{2}$ Ryukoku University, Japan, nisimoto@econ.ryukoku.ac.jp

${ }^{3}$ Queen's University Belfast, United Kingdom, g.philip@qub.ac.uk

Received 26 July 2010; received in revised form 12 January 2011; accepted 27 January 2011

\begin{abstract}
The focus of this paper is to evaluate the benefits of a Japanese e-government project. In this research, the Importance-Performance Analysis (IPA) grid was used to measure the e-government benefits from the users' perspective. A list of 27 government benefits was identified from the e-government literature reviews and each of the benefits was rated using a five point Likert scale. On a five point Likert scale, the online survey enables the users to rate the relative importance of the benefits, followed by another benefit performance rating. The purpose of the survey is not only to measure the actual satisfaction level, but also to highlight important areas for improvements. The IPA, a two-dimensional grid, is broken into four categories: (1) Concentrate Here; (2) Keep Up the Good Work; (3) Low Priority; and (4) Possible Overkill, to enable each of the benefits to be plotted into the grid. It is a clear and powerful evaluation tool for government to find out attributes that are doing well and attributes that need to be improved, which require action immediately. The results are useful in identifying areas for strategic focus to help develop Japan's future e-government strategy.
\end{abstract}

Keywords: E-government, Importance-Performance analysis, E-government benefits, Evaluation methods, Japan 


\section{Introduction}

Although e-government terms have become a buzzword across the world, there is evidence of insufficient or a lack of consensus on the meaning of e-government, especially the main characteristics of e-government [24]. Whether you call it electronic government or digital government, there is a need to understand what has been written in the literature to get a holistic meaning of e-government. While reviewing the e-government literature, we found that there were many versions of e-government definitions. From a technology point of view, e-government: "is about utilizing the Internet and the world-wide-web (WWW) for delivering government information and services to citizens" [52]. From an e-commerce driven perspective, e-government is defined as: "Federal, state, and local government applications that elicit payment or documentation submission over the Net" [46]. However, from a customer relationship driven approach, e-government is seen as: "use by government agencies of information technologies that have the ability to transform relations with citizens, businesses, and other arms of government" [62]. Likewise, Customer Relationship Management (CRM) in e-government is defined as a: "capability that dramatically improves government's relationship with its customers by reorganizing services around actual customer needs" [9]. As we can see over time, e-government concepts have evolved from technological to relational perspectives. It is therefore the goal of this paper to understand customer's motivation in using e-government services to improve their customer relationship and to allocate resources on strategic areas to increase customer satisfaction. Also, in this paper, we will demonstrate the usefulness of Importance-Performance Analysis (IPA) grid in the evaluation of the e-government benefits from user's perspectives in Japan.

\section{E-government Benefits}

Organisations, public or private, both emphasize a high return on investments (ROI). Government increases ROI through improved tax and license fee collections, and cost efficiencies [38]. On the other hand, the private sector increases profit through cross-selling and up-selling products, and improving customer loyalty. On a softer side, both sectors emphasize the importance of customer satisfaction. In an evaluation research by Accenture, the results revealed that $93 \%$ of service providers emphasize the importance of customer satisfaction in developing egovernment initiatives [9]. Furthermore, $83 \%$ of the survey respondents stressed that in the development of egovernment, customer demands for new and better services is crucial. Therefore, it is important to understand customers' needs and wants, especially the benefits that drive them to use e-government services. The egovernment benefits can be categorically broken into two categories: citizen direct benefits (tangible) and citizen indirect benefits (intangible).

Citizen direct benefits are categorically tangible benefits and can be measured in value such as time and cost. Examples of citizen direct benefits are:

- $\quad$ Saving transaction costs;

- $\quad$ Processing transactions speedily;

- $\quad$ High speed accessibility;

- $\quad$ Reducing customers' time spent travelling to government offices;

- $\quad$ Decreased customer queuing time;

- $\quad$ Decreased face-to face-interaction;

- $\quad$ Saving petrol costs;

- $\quad$ Saving parking costs;

- $\quad$ Providing faster access to documents and forms;

- Having a quicker response time to queries;

- $\quad$ Saving postage costs; and

- Reducing the number of customer visits to government offices. 
Citizen indirect benefits are benefits that are difficult to observe, but nevertheless can be realised. Examples of citizen indirect benefits are:

- Being user friendly and easy to use;

- $\quad$ Easy to find information;

- $\quad$ Convenience and availability (i.e. 24 hours a day, 7 days a week);

- Keeping customers' personal and financial information protected;

- Keeping customers' data private (privacy);

- $\quad$ Giving customers caring and individual attention (i.e., referral to a contact person);

- $\quad$ Providing up-to-date information;

- $\quad$ Encouraging active participation from citizens (i.e., e-consultation);

- Communicating in clear and plain language;

- $\quad$ Providing prompt service, and helpful response to customer requests;

- Providing dependable and reliable services;

- Making interaction with government less bureaucratic;

- Increasing customer loyalty and encouraging repeat visits;

- $\quad$ Being accessible for people with disabilities; and

- Increasing government accountability to citizens.

Before deciding which evaluation tools to measure the above-mentioned citizen benefits, we look at numerous evaluation tools that have been applied in e-government.

\section{Existing E-government Evaluation Methods}

Numerous evaluation researches, especially e-government surveys, have been used to review citizen and service provider needs and to examine the quality of e-government websites. Survey methods include face-to-face and telephone interviews with citizens or government officials [2], [9], [46], [47], focus groups [2], visits to government websites [53], [54], [56], and questionnaire surveys to citizens [10]. Examples of practitioners' evaluation tools are shown in Table 1.

The majority of the existing work on e-government focuses on supply side (government providers) [26], [45]. Most of the research surveyed governments to explore the different types of services offered online and to find out barriers that impede the implementation of e-government [19], [35], [61], and United Nation Public Administration Network (UNPAN), on the other hand, benchmarked e-government and ranked e-government at the international level [53], [54]. Numerous supply side approaches of e-government have come under criticisms and most of the critiques are geared towards the problems with supply side benchmarking [4], [25], [36]. It is arguable that some e-government benchmarking researches are biased and not reliable for assessing e-government progress [4] because the result of such benchmarking can favor the country, which initiated the benchmarking activity [4], [26]. Only a handful of survey research was conducted on the demand side - customer [32], [45]. There are two types of customers, namely back end (internal) customer and front end (external) customer. Research in evaluating back end should capture both the organizational and technical infrastructure elements to enable participating organizations to benchmark against each other [25]. Many external customer satisfaction surveys enable respondents to rate how well the organisation or its personnel perform on a series of attributes, which gives little insight into what customers truly want and need from using such e-government services [60].

Apart from the practitioners' evaluation tools, we also considered the commonly used evaluation tools by the academics - SERVQUAL and SERVPERF. SERVQUAL, an evaluation tool [39], has been widely used to measure service quality in both public [11], [37], [57], [58] and private sectors [23], [31]. SERVQUAL also has been used to 
measure service quality of websites [28], [29]. SERVQUAL formula is written as G = P- E, where $G=$ service quality gap; $\mathrm{P}=$ Perception; $\mathrm{E}=$ Expectation. This enables the measurement of gap analysis between the customers' perception and their expectations of actual service quality [11], [39], [57], [58].

Table 1: Practitioners' evaluation tools

\begin{tabular}{|c|c|c|}
\hline $\begin{array}{ll}\text { Project } & \text { name } \\
\text { (organisation) } & \end{array}$ & Methodology and methods & Evaluation objectives: Primary goals \\
\hline 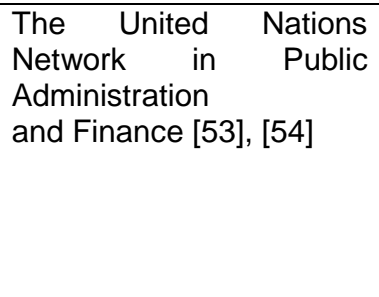 & $\begin{array}{l}\text { Ranks } 191 \text { United Nations (UN) } \\
\text { members according to the } \\
\text { quantitative index of readiness } \\
\text { based on: } \\
\text { (1) website evaluation; } \\
\text { (2) telecommunication } \\
\text { infrastructure; and } \\
\text { (3) human resource endowment. }\end{array}$ & $\begin{array}{l}\text { (1) To present objectively e-government } \\
\text { facts and environment for the UN } \\
\text { participating members. } \\
\text { (2) To encourage UN members to come } \\
\text { up with new innovative ideas in } \\
\text { combating social exclusion through e- } \\
\text { government. }\end{array}$ \\
\hline $\begin{array}{l}\text { Momentum Research } \\
\text { Group [47] }\end{array}$ & $\begin{array}{l}406 \text { interviews were conducted } \\
\text { from citizens and the business } \\
\text { sector. }\end{array}$ & $\begin{array}{l}\text { (1) To benchmark the demand of e- } \\
\text { government services and applications } \\
\text { (2) To understand citizen and business } \\
\text { needs and wants in e-government } \\
\text { contexts and to maximise the } \\
\text { government's ROI. }\end{array}$ \\
\hline Deloitte and Touche [13] & $\begin{array}{l}\text { Use the Citizen Advantage tool to } \\
\text { justify the direct and indirect } \\
\text { savings. }\end{array}$ & $\begin{array}{l}\text { (1) To illustrate the importance of } \\
\text { compliance effects in the use of e- } \\
\text { government. }\end{array}$ \\
\hline Forrester Research [46] & $\begin{array}{l}\text { Conducted } 45 \text { interviews in } \\
\text { Federal, State, and Local } \\
\text { Government; } 15 \text { interviews from } \\
\text { each government level. }\end{array}$ & $\begin{array}{l}\text { (1) To find out how the Federal, State } \\
\text { and Local Governments market their e- } \\
\text { government sites to the users. } \\
\text { (2) To find out what the barriers are that } \\
\text { hinder the e-government initiatives. }\end{array}$ \\
\hline Accenture [9] & $\begin{array}{l}\text { A series of } 143 \text { in-depth telephone } \\
\text { interviews with customer service } \\
\text { senior executives and directors } \\
\text { across } 15 \text { central government } \\
\text { agencies. }\end{array}$ & $\begin{array}{l}\text { (1) To evaluate agencies' attitudes and } \\
\text { action in making CRM a reality. } \\
\text { (2) To identify areas of best practices in } \\
\text { the CRM implementations. }\end{array}$ \\
\hline $\begin{array}{l}\text { Cap Gemini } \text { Ernst \& } \\
\text { Young [56] }\end{array}$ & Web-based survey method & $\begin{array}{l}\text { (1) To benchmark programmes and } \\
\text { assess the progress of eEurope. } \\
\text { (2) To assess the percentage of e- } \\
\text { services made available online in the } 15 \\
\text { EU member countries. }\end{array}$ \\
\hline $\begin{array}{ll}\text { Taylor Nelson } & \text { Sofres } \\
\text { Research [10] } & \end{array}$ & $\begin{array}{l}\text { Approximately } 32,000 \text { individuals } \\
\text { from } 32 \text { countries were interviewed. }\end{array}$ & $\begin{array}{l}\text { (1) To understand the Internet effect on } \\
\text { citizens in the adoption of e-services } \\
\text { globally and nationally }\end{array}$ \\
\hline $\begin{array}{l}\text { World Markets Research } \\
\text { Centre [63] }\end{array}$ & $\begin{array}{l}\text { To evaluate } 2,288 \text { National } \\
\text { Government websites from } 196 \\
\text { countries }\end{array}$ & $\begin{array}{l}\text { (1) To find the differences in national } \\
\text { government websites and to offer ways } \\
\text { to government to upgrade their e- } \\
\text { government sites. }\end{array}$ \\
\hline $\begin{array}{l}\text { Australian government } \\
\text { Information Management } \\
\text { Organisation [2] }\end{array}$ & $\begin{array}{l}5040 \text { interviews were conducted. } \\
\text { Also, four focus groups are } \\
\text { conducted to explore the } \\
\text { motivations and attitudes related to } \\
\text { key findings in the survey. }\end{array}$ & $\begin{array}{l}\text { (1) To understand the users' } \\
\text { demographic, behaviours in using e- } \\
\text { government services. } \\
\text { (2) To identify e-government barriers. } \\
\text { (3) To measure customer satisfaction. }\end{array}$ \\
\hline
\end{tabular}


Even though SERVQUAL has been widely used by academics to measure service quality, it has also been highly criticised by many researchers [6], [7], [8], [43], [55]. For example, the famous SERVQUAL five dimensions fail to be replicated [6]. Also, SERVQUAL is not universal because it lacks customisation abilities, and there was recommendation of the use of importance being assigned to each of the items to allow differences between each attribute of the service quality to be identified [6]. Another problem is that the SERVQUAL's gap scale, and the average scores across the five dimensions, cannot be justified because of the dimension structure's instability [55]. To solve that problem, the researchers suggested that each of the items should be treated individually. Also, in response to the SERVQUAL debates, there are new suggestions to use the evaluation tool with either the perception or expected scale, but not the difference between them [8]. Thus, a new performance-based service quality measurement tool called SERVPERF was developed [7]. SERVPERF measures only the performance level of the service quality. With the recommendation of the use of importance [6] and the SERVPERF emphasis of the importance of performance being assigned to the measured attributes [7], therefore, the adoption of importanceperformance is important.

\subsection{The Importance of the IPA Model}

After a comprehensive literature review of e-government, we discovered that many service industry researchers and practitioners normally used a one-sided survey to measure only satisfaction levels. As mentioned earlier, instead of measuring only the satisfaction levels, it is suggested that the importance indicator to be assigned to the items surveyed to rank the importance of the attributes [6]. Many customer satisfaction tools [2], SERVQUAL [40] and SERVPERF [7] failed to include such importance ranking in their survey method. To address this problem, the IPA, a simple evaluation tool, is used to understand customer satisfaction and prioritise areas for improvement [30]. Even the strong advocates of SERVPERF [7] recommended the use of importance-performance in measuring service quality. IPA has been widely used in service industries such as travel and tourism [15], [16], [18], education [27], [34], hospitals [20], [64], and other sectors [5], [14]. IPA is more superior than both SERVPERF and SERVQUAL because it has the importance attribution to the items and moreover, IPA can be plotted graphically using the importance and performance for each attribute. In addition, many practitioners found SERVQUAL and SERVPERF too technical and information collected from such approaches can be difficult to understand. IPA, on the other hand, is a powerful evaluation tool for practitioners and academics to find out attributes that are doing well and attributes that need to be improved, which require actions immediately [59]. In short, this IPA evaluation tool is used to prescribe the prioritisation of attributes for improvement and it can also provide guidance for strategic development [49].

The two dimensional IPA model is divided into four quadrants with performance on the x-axis and importance on the $y$-axis. As a result of this, four quadrants namely Concentrate Here, Keep up the Good Work, Low Priority, and Possible Overkill are created. The quadrants can be used to generate suggestions for e-government managers by differentiating between them [59].

Quadrant I (High Importance/Low Performance) is labelled Concentrate Here. Attributes that fall into this quadrant represent key areas that need to be improved with top priority.

Quadrant II (High Importance/High Performance) is labelled Keep up the good work. All attributes that fall into this quadrant are the strength and pillar of the organisations, and they should be the pride of the organisations.

Quadrant III (Low Importance/Low Performance) is labelled Low Priority. Thus, any of the attributes that fall into this quadrant are not important and pose no threat to the organisations.

Quadrant IV (Low Importance/High Performance) is labelled as Possible Overkill. It denotes attributes that are overly emphasized by the organisations; therefore, organisations should reflect on these attributes, instead of continuing to focus in this quadrant, they should allocate more resources to deal with attributes that reside in quadrant I.

An example of an IPA grid is shown in Figure 1. 


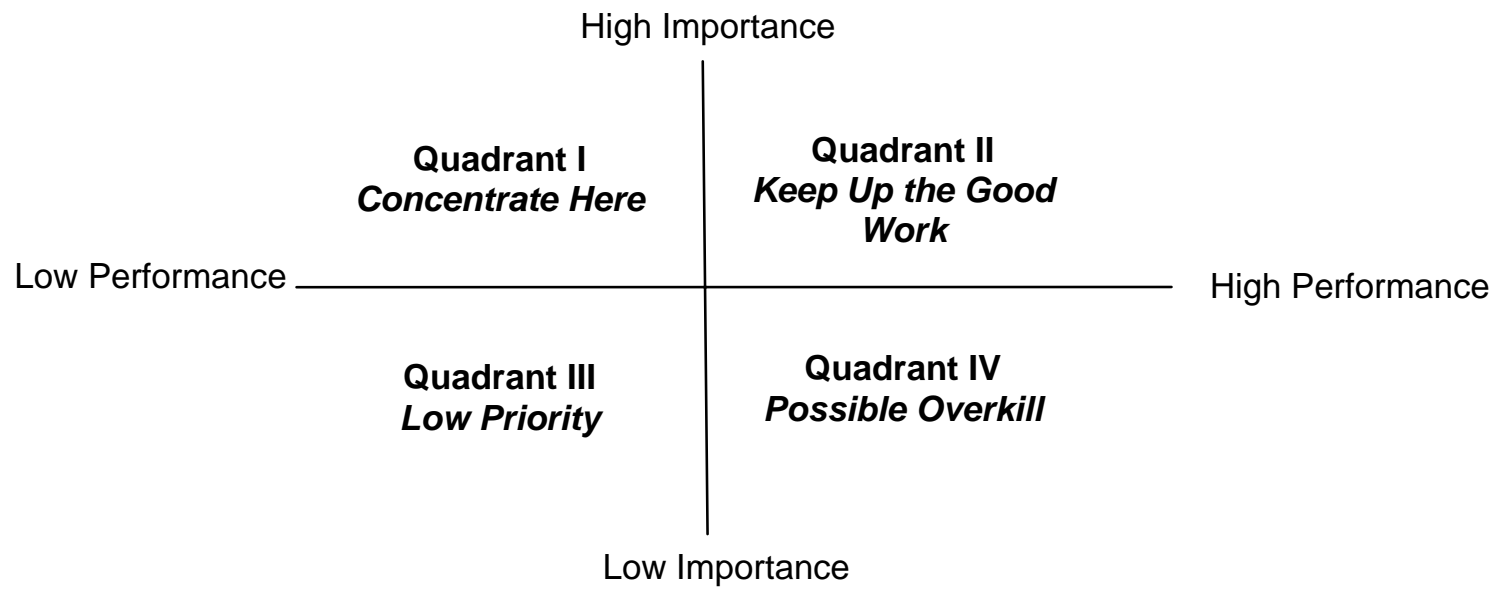

Figure 1: The original IPA framework. Source [30]

The IPA evaluation tool can help to evaluate e-government benefits and to provide guidance to formulate egovernment strategy to allocate resources accurately to maximise a high ROI [59]. The IPA model is used to evaluate the level of importance citizens attach to each of the benefits and also to examine the level of satisfaction perceived by them in the delivery of those benefits.

\section{Methodology and Data Collection}

This research project used a survey method to measure the perception of Ryukoku's alumni as e-government users. Given the fact that many alumni are geographically dispersed, the use of an online survey was highly recommended. This e-government research project used similar questionnaires to those successfully used by a group of Malaysia government researchers to evaluate Japanese users' perspectives on the quality of e-government services [59]. Invitational emails were sent to Ryukoku's alumni informing them about the e-government survey project and to solicit their input about their e-government experiences. We used a five point Likert scale to measure the importance ( 1 = very unimportant to $5=$ very important) and performance $(1=$ very unsatisfied to $5=$ very satisfied $)$ attributed to each benefit. In total there were 27 benefits identified from the e-government literature. The survey begins with questions about the types of e-government services used by the users, followed by the IPA evaluation, open-ended questions and users' demographic. Empirical data was collected electronically and in total, 107 alumni members filled in the survey and amongst those respondents, 46 are female and 61 are male, in which $45 \%$ of the total respondents are single. The significance and the reliability of the IPA grid have been tested successfully [48]. It is also cautioned that if the survey response rate is low, the possibilities of over-represented and under-represented populations may occur [19], [45]. While the response rate to a survey can vary, a general rule of thumb is to have at least 100 survey responses, which is achieved in this research.

\section{E-government Experience in Japan}

Japan, a highly industrialised technological country in Asia, is considered a developed country. Famous for its Kaizen or continuous improvement concepts, there is no doubt that Japan is highly efficient when it comes to international trading; therefore, it is not surprising that Japan is ranked as having the second largest Gross National Product (GNP) economic growth in the world. In today's world, Information and Communication Technology (ICT) has become one of the drivers in economic growth. ICT has played an important role in Japanese economic growth, and also in another report by UNPAN, Japan is considered as one of the South East Asian countries that has a high level of fixed line, mobile phones and Internet usage [33]. Such first world infrastructures have facilitated government providers to implement e-government services for the use of the citizen [53].

In 2001, an e-government research study conducted by both the United Nations Division for Public Economics and Public Administration (UNDPEPA) and the American Society for Public Administration (ASPA), revealed that Japan was ranked $27^{\text {th }}$ internationally and was the $30^{\text {th }}$ e-government leader in the world [52]. This UNPAN research used two methodologies to benchmark a global e-government index [52]. Firstly, the national e-government website was analysed for its content and type of services provided followed by a statistical analysis comparing human capital and ICT infrastructure of UN member states. In 2003, Japan's e-government had improved and it climbed to $18^{\text {th }}$ position. Japan maintained this position in 2004. However, Japan's e-government ranking made a leap from $18^{\text {th }}$ to $14^{\text {th }}$ in 2005 [53]. Such an improvement was due to Japan's proactive role in e-participation, which includes features that 
encourage citizen engagement (i.e., feedback). UNPAN found that although the Japanese e-government portal (Site 1) provides documents for consultation, the feedback was still collected offline [53]. Japan's m-government, known as Keitai, facilitates content services offered by eight government agencies which are accessible using wireless devices (i.e., mobile phones and Personal Digital Assistants (PDAs)). Information such as environmental situations (i.e., weather and road traffic), maritime (i.e., navigation alerts), immigration (i.e., passport and visa applications), crimes (i.e., information about wanted criminals), Frequently Asked Questions (FAQ) (i.e., government policies) are made available using Keitai services. In 2008, Japan's e-government climbed to 11th position and settled in $17^{\text {th }}$ position in 2010 [54]. Although the Japanese e-government is considered one of the top 20 e-government leaders in the world, it still needs to improve its e-government services by responding to the needs and wants of its citizens.

Previous research on e-government, specifically assessing e-government progress, had mainly focused on benchmarking of countries based on different sets of indicators [26]. However, no research has been made to assess the service benefits of Japanese e-government services. There is also lack of research in the demand side (customers' perspectives) about the importance and performance of realized benefits in using e-government services in Japan. One of the main knowledge gaps that would be addressed in this research is the introduction of Importance-Performance Analysis (IPA) as a strategic decision making tool that can assist IS decision makers in Japan to strategically allocate resources to improve E-Government services. There is also lack of e-government evaluation research in Japan, and it is the intention of this research to fill the knowledge gap, which includes exploring: (i) the general perception of user about Japan's e-government services; (ii) the ranking of e-government benefits; and (iii) customer's rating of importance and performance of e-government benefits realized when they used e-government services.

In this research, the IPA is used to evaluate the quality of online services provided by Japanese e-government portal (Site 1). This national website provides services such as:

1. Police legal counsel and communication services;

2. School education and learning information;

3. Employment and the national insurance system;

4. Health issues;

5. Income tax issues;

6. Driver's license and payment of road and automobile tax;

7. Marriage and business certificates; and

8. Information about travelling and nationwide transportation.

According to Internet World Stats (Site 2), as of September 2009, 75.5\% of the Japanese population was Internetenabled. With such a high percentage of the Japanese population using the Internet, it is definitely good to perform an evaluation of benefits on the e-government services with a hope of clearly understanding the needs and wants of the users to better serve them in the future. The IPA evaluation tool can highlight strategic areas for government to focus on and hence maximise the resources to gain higher customer satisfaction.

\section{Discussion of Findings}

The findings are presented in three sections:

1. The general perception of Japan's e-government services;

2. E-government benefit ranking analysis; and

3. The graphical plotting of benefits on the IPA grid.

\subsection{General Perception of Japan's E-government Services}

Respondents were asked to rate using a five point Likert scale, with items regarding the overall service quality of the e-government services. Scale anchors ranged from: very good (5); good (4); neutral (3); bad (2); to very bad (1). On average, the respondents rated 2.72 for the overall service quality of Japanese e-government services. Respondents were asked again, on a rating of 5 (definitely not (1); probably not (2); might or might not (3); probably (4); definitely 
(5)), how likely they were to use the e-government services again and how likely they were to recommend the services to others. As for the former question, the respondents rated encouragingly 3.50, which shows that the majority of the respondents will use the e-government services again. However, as for the latter question, the respondents rated 3.01 on the scale of e-government services recommendations, which means they are taking a neutral stance towards the recommendation of such similar e-government services to others.

It is important to measure citizens' perceptions on the after use effects of the e-government services whether such egovernment services are: (1) essential; (2) improving public services; (3) wasting public money; (4) creating better relationships between citizens and government; (5) important to make well-informed decisions. Interestingly, $46.7 \%$ of the respondents disagreed that the use of e-government services can help to create a better relationship between citizens and government. More than half of the respondents (58.9\%) agreed that the use of e-government services can help to make well-informed decisions. For details please see Table 2.

Table 2: Citizens' perception on the after use of e-government services

\begin{tabular}{|l|c|l|l|l|l|}
\hline \multicolumn{2}{|c|}{ As a result of using e-government services, I am convinced that such services are: } \\
\hline & Essential & $\begin{array}{l}\text { Improving } \\
\text { public } \\
\text { services }\end{array}$ & $\begin{array}{l}\text { Wasting } \\
\text { public } \\
\text { money }\end{array}$ & $\begin{array}{l}\text { Creating better } \\
\text { relationships between } \\
\text { citizens } \\
\text { government }\end{array}$ & $\begin{array}{l}\text { Important } \\
\text { and } \\
\text { make } \\
\text { informed } \\
\text { decisions }\end{array}$ \\
\hline Yes & $36.4 \%$ & $32.7 \%$ & $41.1 \%$ & $8.4 \%$ & $58.9 \%$ \\
\hline No & $22.4 \%$ & $24.3 \%$ & $28.0 \%$ & $46.7 \%$ & $14.0 \%$ \\
\hline Do not know & $41.1 \%$ & $43.0 \%$ & $30.8 \%$ & $44.9 \%$ & $27.1 \%$ \\
\hline
\end{tabular}

\subsection{E-government Benefit Ranking Analysis}

Table 3 shows the top 10 most important benefits from the perspective of the citizen. As we can see, citizens ranked convenience and availability: 24 hours a day, 7 days a week (B14); processing transactions speedily (B2); reducing time spent travelling to government offices (B4); high speed accessibility (B3) and; providing faster access to documents and forms (B9) as the most important benefits that drive them to use e-government services. Interestingly, all the mentioned benefits are categorically related to speed and time.

Table 3: Top 10 benefits of 'importance' to citizens

\begin{tabular}{|c|c|c|c|c|c|}
\hline & Benefits & $\begin{array}{l}\text { Mean } \\
\text { Imp. }\end{array}$ & $\begin{array}{l}\text { Rank } \\
\text { Imp. }\end{array}$ & $\begin{array}{l}\text { Mean } \\
\text { Per. }\end{array}$ & $\begin{array}{l}\text { Rank } \\
\text { Per. }\end{array}$ \\
\hline B14 & $\begin{array}{l}\text { Convenience and available at anytime ( } 24 \text { hours a } \\
\text { day, } 7 \text { days a week) }\end{array}$ & 4.46 & 1 & 3.74 & 1 \\
\hline B2 & Processing transactions speedily & 4.44 & 2 & 3.36 & 10 \\
\hline B4 & $\begin{array}{l}\text { Reduce customers' time spent travelling to the } \\
\text { government office }\end{array}$ & 4.37 & 3 & 3.60 & 3 \\
\hline B3 & High speed accessibility & 4.30 & 4 & 3.62 & 2 \\
\hline B9 & Providing faster access to documents and forms & 4.23 & 5 & 3.48 & 6 \\
\hline B13 & Easy to find information & 4.21 & $=6$ & 3.50 & 4 \\
\hline B5 & Decreased customer queuing time & 4.21 & $=6$ & 3.49 & 5 \\
\hline B18 & Providing up-to-date information & 4.21 & $=6$ & 3.47 & 7 \\
\hline B16 & Keeping customer data private (privacy) & 4.17 & 7 & 3.16 & 14 \\
\hline B15 & $\begin{array}{l}\text { Keeping customer personal and financial information } \\
\text { protected (security) }\end{array}$ & 4.15 & 8 & 3.01 & 17 \\
\hline B1 & Saving transaction costs & 4.09 & 9 & 3.20 & 13 \\
\hline B10 & Having a quicker response time to queries & 3.96 & 10 & 3.05 & 15 \\
\hline
\end{tabular}

The mean importance for all the 27 benefits was rated at 3.86, whereas the mean satisfaction was just an average of 3.19 (see Appendix A). Therefore, if we were to plot the importance and performance on the IPA grid, government leaders and strategists would be able to quickly identify areas in which e-government should allocate their resources to maximise a high ROI. This is reflected in the IPA shown in Figure 2. 


\subsection{Graphical Plotting of Benefits on the IPA Grid}

The intersection in the IPA is made available using the mean level of importance at 3.86 and the mean level of performance 3.19. In quadrant I, Concentrate Here, citizens perceive the attributes as very important, but the perceptions of performance levels are below average. Thus, further improvement efforts should be concentrated here. There are five attributes that fall into this quadrant.

- $\quad$ Having a quicker response time to queries (B10).

- $\quad$ Keeping customers' personal and financial information protected (security) (B15).

- $\quad$ Keeping customer data private (privacy) (B16).

- $\quad$ Providing prompt service, and helpful response to customer requests (B21).

- $\quad$ Being accessible for people with disabilities (B25).

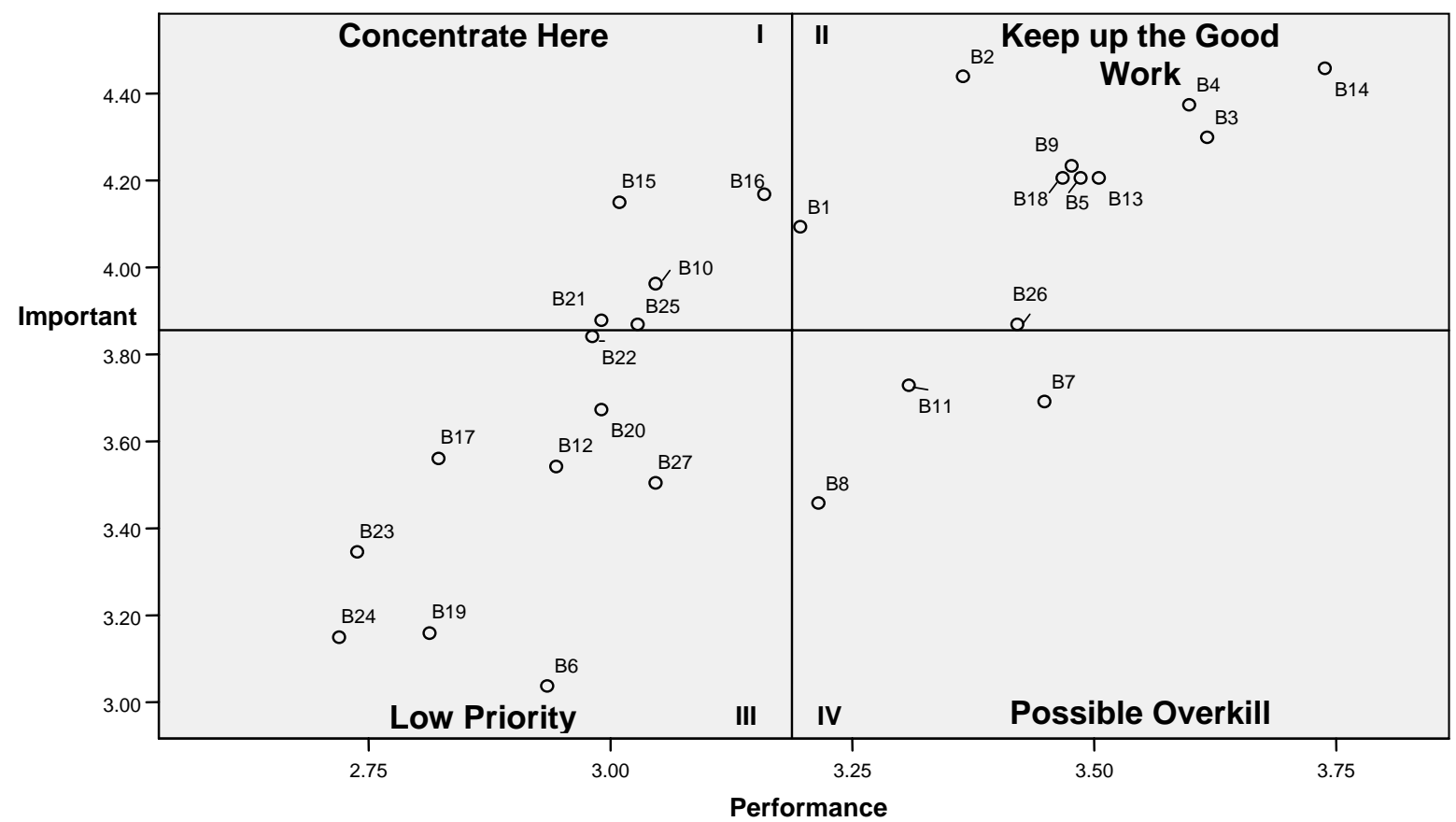

Figure 2: Citizen IPA grid

Indirect benefits such as security and privacy issues are important to build customers' trust in using e-government [32]. In another research by World Markets, it found out that $2 \%$ of government websites are disabled friendly [63]. Many of such important attributes can only be improved when the government knows what is important and what is not important and also how satisfied their citizens are in getting those benefits.

Benefits such as: (B1) saving transaction costs; (B2) processing transactions speedily; (B3) high speed accessibility; (B4) reducing customers' time spent travelling to government offices; (B5) decreased customer queuing time; (B9) providing faster access to documents and forms; (B13) easy to find information; (B14) convenience and availability (24 hours a day, 7 days a week); (B18) providing up-to-date information; and (B26) reducing the number of customer visits to government office, situated in quadrant II, Keep Up the Good Work, are perceived to be very important and satisfied from the customers' perspective. All these e-government benefits are the strengths of the organisations and the government agencies should keep up the good work in maintaining or delighting their customers, as otherwise, these benefits might risk falling into the Concentrate Here quadrant.

Some of the benefits that are literally categorised as Low Priority in quadrant III are:

- $\quad$ Decreased face-to-face interaction (B6);

- $\quad$ Being user friendly and easy to use (B12); 
- $\quad$ Giving customers caring and individual attention (i.e., referral to a contact person) (B17);

- $\quad$ Encouraging active participation from citizens (i.e., e-consultation) (B19);

- $\quad$ Clear and written in plain language (B20);

- $\quad$ Providing dependable and reliable services (B22);

- $\quad$ Make interaction with the government less bureaucratic (B23);

- Increasing customers' loyalty and encouraging repeat visits (B24);

- Increasing government accountability to citizens (B27).

In quadrant IV, Possible Overkill, there are three direct benefit attributes namely: saving (B7) petrol; (B8) parking; and (B11) postage costs that are rated by customers as of low importance with high performance. Here, the customers are very satisfied with the organisation's performance, but all the continuous effort in delivering those benefits to the customers will be futile if customers are already content. Therefore, present efforts on these attributes in this quadrant are exaggerated and government planners should consider allocating resources (i.e., money, effort, and time) elsewhere, especially on those benefits in the Concentrate Here quadrant, to yield a higher return.

This research study managed to provide useful recommendations for e-government planners or policy makers for developing e-government strategies in the future. The IPA grid reveals areas of strategic focus, i.e., Concentrate Here quadrants with findings in this area that require the greatest attention. Also, to be highlighted in this paper is that the identification of those who judge the importance and performance of each of the benefits is clear because the Ryukoku's alumni members are clearly working class citizens and only respondents that have used egovernment services were asked to complete the survey. It is likely that the general population would have a different view on the importance and performance in the above-mentioned attributes; therefore, further research should be conducted to gauge the perception of the overall Japanese citizen on the quality of e-government services in Japan in the future.

\section{Conclusions}

In this paper, the IPA technique is discussed and applied to measure e-government benefits from the perspective of Japanese e-government users to find focus areas for the allocation of resources. An online survey was developed to survey users' perceptions to identify areas of importance and areas of satisfaction/dissatisfaction, which then enable government providers to strategically identify focus areas to improve e-government services. IPA is a strategic tool that can quickly enable e-government planners to understand customers' needs and wants (important prioritisation areas) and also to assess customers' satisfaction rather than relying on performance indicators alone.

In this research, the Japanese public managers and IS decision makers should focus on the Concentrate Here benefits, and allocate resources to improve e-government systems to: (a) quicken response time to queries; (b) keep customer's personal and financial information protected; (c) keep customer data private; (d) provide prompt service, and helpful response to customer requests; and be accessible for people with disabilities. In the Possible Overkill quadrant, there is an overemphasis in the government's allocation of resources on attributes that are deemed to be unimportant and it is time to consider divesting investment in these areas by allocating more resources to Concentrate Here quadrant. While this research manages to evaluate customers' perspectives (demand side) on the importance and performance of benefit gains in using e-government services, we believe that a similar evaluation method can be applied in future research to measure government providers' (supply side) perspectives on the benefits of providing e-government services.

Also for future research, there are plans to extend the one-sided IPA evaluation tool further by cross-matching the importance and satisfaction levels attached by customers and service providers to each of the E-Government benefits. For example, the IPA evaluation tool can be extrapolated to become Importance-Importance Analysis (IIA) and Performance-Performance Analysis (PPA) from citizen and service provider perspectives. For the IIA evaluation tool, we can find the gap analysis by comparing the importance levels attached by both citizen and service provider to each of the benefits. Likewise, the PPA evaluation tool can be used to identify the relative satisfaction of the benefit attributes associated with e-government services. To conclude, this IPA grid is useful for information systems (IS) managers or researchers to evaluate e-government service quality by prioritising or focusing on areas where improvement is needed without wasting taxpayers' money. There is a limitation to the interpretation of the results because the collected data was mainly from Ryukoku alumni, which may not be representative of the whole population in Japan. Although the survey research received good responses from 107 participants, further study is still recommended to further validate the findings and also to make the findings more generalisable to the whole population. One of the options to further validate the findings would be to conduct an online survey and link it to the main Japanese e-government portal to gauge citizens' perception on the use of the Japanese e-government services. 


\section{Websites List}

Site 1: Japan e-government portal

http://www.e-gov.go.jp

Site 2: Internet World Stats

http://www.internetworldstats.com

\section{References}

[1] Aamva, E-Government: A cost model to compare the marginal costs of traditional DMV transaction delivery to an e-government delivery system. AAMVA Electronic Government Working Group, America, 2001.

[2] Agimo. (2003, March) E-Government Benefits Study. Australian Government Information Management Office (AGIMO). [Online]. Available: http://www.agimo.gov.au/archive/publications noie/2003/03/egovt benefits study.html.

[3] Agimo. (2004, October) E-Government Benefits Study, Australian Government Information Management Office (AGIMO). [Online]. Available: http://www.agimo.gov.au/archive/publications noie/2004/10/annrep0304/part 3 - performance report.html.

[4] F. Bannister, The curse of the benchmark: an assessment of the validity and value of e-government comparisons, International Review of Administrative Sciences, vol. 73, no. 2, pp. 171-188, 2007.

[5] J. E. Blose, W. B. Tankersley, and L. R. Flynn, Managing service quality using data envelopment analysis, Quality Management Journal, vol. 12, no. 2, pp. 7-24, 2005.

[6] J. H. Carman, Consumer perceptions of service quality: An assessment of the SERVQUAL dimensions, Journal of Retailing, vol. 66, no. 1, pp. 33-55, 1990.

[7] J. Cronin and S. A. Taylor, Measuring service quality: A reexamination and extension, Journal of Marketing, vol. 56, no. 3, pp. 55-67, 1992.

[8] J. Cronin and S. A. Taylor, SERVPERF versus SERVQUAL: Reconciling performance-based and perceptionsminus-expectations measurement of service quality, Journal of Marketing, vol. 58, no. 1, pp. 125-131, 1994.

[9] P. Crook, S. J. Rohleder, and A. Simmonds, CRM in Government: Bridging the Gaps. Atlantic and Europe, Accenture, 2003.

[10] A. Dexter and V. Parr, Government Online Study, Taylor Nelson Sofres, 2003.

[11] M. Donnelly, M. Wisniewski, J. F. Dalrymple and A. C. Curry, Measuring service quality in local government: the SERVQUAL approach, International Journal of Public Sector Management, vol. 8, no. 7, pp. 15-21, 1995.

[12] W. D. Eggers, Citizen Advantage: Enhancing Economic Competitiveness Through E-Government, Deloitte \& Touche, 2004.

[13] W. Eggers and S. Goldsmith, Government by Network: The New Public Management Imperative. Deloitte Research and the Ash Institute for Democratic Governance and Innovation at the John F. Kennedy School of Government, Harvard University, U.S.A., 2004.

[14] C. T. Ennew, G. V. Reed, and M. R. Binks, Importance-performance analysis and the measurement of service quality, European Journal of Marketing, vol. 27, no. 2, pp. 59-70, 1993.

[15] M. J. Enright and J. Newton, Determinants of tourism destination competitiveness in asia pacific: Comprehensiveness and Universality, Journal of Travel Research, vol. 43, no. 4, pp. 339-350, 2005.

[16] W. Fache, Methodologies for innovation and improvement of services in tourism, Managing Service Quality, vol. 10, no. 6, pp. 356-366, 2000.

[17] M. Forman, E-Government Strategy: Simplified Delivery of Services to Citizens. Washington: E-Government Strategy, 2002.

[18] F. Go and W. Zhang, Applying importance-performance analysis to Beijing as an international meeting destination, Journal of Travel Research, vol. 35, no. 4, pp. 42-49, 1997.

[19] D. A. Goings, D. Young and S. H. Hendry, Critical factors in the delivery of e-Government services: Perceptions of technology executives, Communications of the International Information Management Association, vol. 3, no. 3, pp. 2-15, 2003.

[20] J. M. Hawes and C. P. Rao, Using importance-performance analysis to develop health care marketing strategies, Journal of Health Care Marketing, vol. 5, no. 4, pp. 19-25, 1985.

[21] G. Hutton, Building a Business Case for E-Government Portals, Anti-Terrorism Force, Protection Office, Vignette Corporation, 2003.

[22] Information Society Commission, E-Government: More Than an Automation of Government Services, Department of the Taoiseach, 2003.

[23] H. Ingram and G. Daskalakis, Measuring quality gaps in hotels: the case of Crete, International Journal of Contemporary Hospitality Management, vol. 11, no. 1, pp. 24-31, 1999.

[24] P. T. Jaeger and K. M. Thompson, E-government around the world: Lessons, challenges and future directions, Government Information Quarterly, vol. 20, no. 4, pp. 389-394, 2003.

[25] M. Janssen, Measuring and Benchmarking the Back-end of E-Government: A participative self-assessment approach, in Proceedings of $9^{\text {th }}$ IFIP WG 8.5 International Conference, EGOV 2010, Lausanne, Switzerland, 2010, pp. 156-167. 
[26] D. Janssen, S. Rotthier, and K. Snijkers, If you measure it, They Will Score: An Assessment of International Egovernment Benchmarking, Information Polity, vol. 9, no. 3-4, pp.121-130, 2004.

[27] M. Joseph and B. Joseph, Service quality in education: a student perspective, Journal Quality Assurance in Education, vol. 5, no. 1, pp. 15-21, 1997.

[28] Y. Kuo, A study on service quality of virtual community websites, Total Quality Management \& Business Excellence, vol. 14, no. 4, pp. 461-474, 2003.

[29] Y. N. Li, K. C. Tan and M. Xie, Measuring web-based service quality, Total Quality Management, vol. 13, no. 5, pp. 685-701, 2002.

[30] J. Martilla and J. James, Importance-performance analysis, Journal of Marketing, vol. 41, no. 1, pp. 77-79, 1977.

[31] JR. G. Milbourn, Quality service makes happy customers and greater profits, Business Forum, vol. 23, no. 3, pp. 15-19, 1998.

[32] Momentum Research Group. (2000, July) Benchmarking the eGovernment Revolution: Year 2000 report on citizen and business demand. Cunningham Communication Commissioned by NIC. [Online]. Available: http://www.egov.com/Pages/default.aspx.

[33] T. Murakami. (1997, July) The Impact of ICT on Economic Growth and the Productivity Paradox, Center for Knowledge Exchange \& Creation, Nomura Research Institute. [Online]. Available: http://www.nomurafoundation.or.jp/data/19971011 Takeshi Murakami 2.pdf.

[34] R. D. Nale, D. A. Rauch, and S. A. Wathen, An exploratory look at the use of importance performance analysis as a curricular assessment tool in a school of business, Journal of Workplace Learning: Employee Counselling Today, vol. 12, no. 4, pp. 139-145, 2000.

[35] D. F. Norris and M. J. Moon, Advancing E-government at the grassroots: tortoise or hare?, Public Administration Review, vol. 65, no. 1, pp. 64-75, 2005.

[36] A. Ojo, T. Janowski, and E. Estevez, Determining progress towards E-government: What are the core indicators?, in Proceedings of $5^{\text {th }}$ European Conference on E-Government, Antwerpen, 2005, pp. 313-322.

[37] R. A Orwig and J. Pearson, An empirical investigation into the validity of SERVQUAL in the Public Sector, Public Administration Quarterly, vol. 21, no. 1, pp. 54-69, 1997.

[38] D. Osborne and T. Gaebler, Reinventing Government: How the Entrepreneurial Spirit is Transforming the Public Sector, Reading: Addison-Wesley, 1992.

[39] A. Parasuraman, V. A. Zeithaml, and L. L. Berry, SERVQUAL: A Multiple-Item scale for measuring consumer perceptions of service quality, Journal of Retailing, vol. 64, no. 1, pp. 5-6, 1988.

[40] A. Parasuraman, V.A. Zeithaml, and L.L. Berry, A conceptual model of service 1uality and its implications for future research, Journal of Marketing, vol. 49, no. 4, pp. 41-50, 1985.

[41] Pathfinders. (2002) A Guide to Implementing CRM in Local Government. Office of the Deputy Prime Minister, UK. [Online]. Available: http://www.legsb.gov.uk/.

[42] Peoplesoft, Creating a constituent-focused government, PeopleSoft Inc, Pleasanton, 2009.

[43] G. Philip and S. A. Hazlett, The measurement of service quality (of information services): A proposed new P-CP attributes model, International Journal of Quality and Reliability Management, vol. 14, no. 3, pp. 260-286, 1997.

[44] PMA, Implementing the President's Management Agenda for E-Government. Office of Management and Budget, Executive Office of the President of the United States, 2003.

[45] C. G. Reddick,Citizen interaction with E-government: From the streets to servers?, Government Information Quarterly, vol. 22, no. 1, pp. 38-57, 2005.

[46] J. Sharrard, J.C. Mccarthy, M.J. Tavilla, J. Stanley, Sizing US eGovernment, The Forrester Report, 2000.

[47] J. Shutter and E. Graffenreid. (2000, October) Benchmarking e-Government. NIC publications, Momentum Research Group. [Online]. Available: http://www.nicusa.com/pdf/EGOV Benchmark.pdf.

[48] W. Skok, A. Kophamel, and I. Richardson, Diagnosing information systems success: importance - performance maps in the health club industry, Information \& Management, vol. 38, no. 7, pp. 409-419, 2001.

[49] N. Slack, The importance-performance matrix as a determinant of improvement Priority, International Journal of Operations \& Production Management, vol. 14, no. 5, pp. 59-75, 1994.

[50] D. Souder, CRM improves citizen service in Fairfax County, Public Management, vol. 83, no. 4, pp. $14,2001$.

[51] M. Symonds, Government and the internet: Sign on the dot.com line, The Economist, vol. 355, no. 8176, pp. 27, 2000.

[52] UNPAN. (2001, July) Benchmarking E-Government: A Global Perspective - Assessing the Progress of the UN Member. [Online]. Available: http://www2.unpan.org/egovkb/global reports/05report.htm.

[53] UNPAN. (2005, July) Global Readiness Report: From eGovernment to elnclusion. [Online]. Available: http://www2.unpan.org/egovkb/global reports/05report.htm.

[54] UNPAN. (2010 July) Leveraging E-government at a Time of Financial and Economic Crisis. [Online]. Available: http://www.unpan.org/egovkb/global reports/08report.htm.

[55] T. P. Van Dyke and L. A. Kappelman, Measuring information systems service quality: Concerns on the use of the SERVQUAL questionnaire, MIS Quarterly, vol. 21, no. 2, pp. 195-208, 1997.

[56] P. Wauters and P. V. Durme, Online Availability of Public Services: How Does Europe Progress? Web Based Survey on Electronic Public services, Cap Gemini Ernst \& Young, 2004.

[57] M. Wisniewski and M. Donnelly, Measuring service quality in the public sector: The potential for SERVQUAL, Total Quality Management, vol. 7, no. 4, pp. 357-367, 1996.

[58] M. Wisniewski, Assessing customer satisfaction with local authority services using SERVQUAL, Total Quality Management, vol. 12, no. 7, pp. 995-1003, 2001. 
[59] M. S. Wong, C. Fearon, and G. Philip, Evaluating E-government in Malaysia: An importance-performance grid analysis (IPA) of citizens and service providers, International Journal of Electronic Business, vol. 7, no. 2, pp. 105-129, 2009.

[60] M. S. Wong, Evaluating E-Government in Malaysia: The Use of ROI Vs ROR Matrix to Evaluate E-Filing Services, in proceedings of EGOV 2010, Lausanne, Switzerland, 2010, pp. 114-124.

[61] M.S. Wong, S. Jackson, G. Philip, Cultural issues in developing e-government in Malaysia, Behaviour and Information Technology, vol. 29, no. 4, pp. 423-432, 2010.

[62] World Bank. (2002, March) Electronic Government and Governance: Lessons for Argentina, The World Bank Group. [Online]. Available: http://www-wds.worldbank.org.

[63] World Markets. (2001, October) World Markets Research Centre Global E-Government Survey. [Online]. Available: http://www-it.fmi.uni-sofia.bg/eg/res/e-govreport.pdf.

[64] U. Yavas and D. J. Shemwell, Modified importance-performance analysis: an application to hospitals, International Journal of Health Care Quality Assurance, vol. 14, no. 3, pp. 104-110, 2001. 


\section{Appendix A: E-government Benefits}

\begin{tabular}{|l|l|c|c|}
\hline \multicolumn{1}{|c|}{ Benefits } & Important & Performance \\
\hline B1 & Saving transaction costs [1] & 4.09 & 3.20 \\
\hline B2 & Processing transaction speedily [21], [44] & 4.44 & 3.36 \\
\hline B3 & High speed accessibility [50] & 4.30 & 3.62 \\
\hline B4 & $\begin{array}{l}\text { Reducing customers' time spent traveling to the government } \\
\text { offices [1], [12], [21] }\end{array}$ & 4.37 & 3.60 \\
\hline B5 & Decrease customer queuing time [51] & 4.21 & 3.49 \\
\hline B6 & Decrease face to face interaction [3] & 3.04 & 2.93 \\
\hline B7 & Save petrol costs [12] & 3.69 & 3.45 \\
\hline B8 & Save parking costs [12] & 3.46 & 3.21 \\
\hline B9 & Provide faster access to documents and forms [3] & 4.23 & 3.48 \\
\hline B10 & Having a quicker response time to queries [1] & 3.96 & 3.05 \\
\hline B11 & Save postage costs [12] & 3.73 & 3.31 \\
\hline B12 & Being user friendly and easy to use [3] & 3.54 & 2.94 \\
\hline B13 & Easy to find information [3] & 4.21 & 3.50 \\
\hline B14 & $\begin{array}{l}\text { Convenience and availability (i.e. 24 hours a day, 7 days a } \\
\text { week) [1], [21] }\end{array}$ & 4.46 & 3.74 \\
\hline B15 & $\begin{array}{l}\text { Keeping customers' personal and financial information protected } \\
\text { (Security) [51] }\end{array}$ & 4.15 & 3.01 \\
\hline B16 & Keeping customers' data private (Privacy) [51] & 4.17 & 3.16 \\
\hline B17 & $\begin{array}{l}\text { Giving customers caring and individual attention (i.e., referral to } \\
\text { a contact person) [21] }\end{array}$ & 3.56 & 2.82 \\
\hline B18 & Providing up-to-date information [3] & 4.21 & 3.47 \\
\hline B19 & $\begin{array}{l}\text { Encouraging active participation from citizens (i.e., e- } \\
\text { consultation) [22] }\end{array}$ & 3.16 & 2.81 \\
\hline B20 & Communicating in clear and plain language [3] & 3.67 & 2.99 \\
\hline B21 & $\begin{array}{l}\text { Providing prompt service, and helpful response to customer } \\
\text { requests [1] }\end{array}$ & 3.88 & 2.99 \\
\hline B22 & providing dependable and reliable services [3] & 3.84 & 2.98 \\
\hline B23 & Making interaction with government less bureaucratic [3] & 3.35 & 2.74 \\
\hline B24 & Increasing customer loyalty and encouraging repeat visits [41] & 3.15 & 2.72 \\
\hline B25 & Being accessible for people with disabilities [42] & 3.87 & 3.03 \\
\hline B26 & $\begin{array}{l}\text { Reducing the number of customer visits to government } \\
\text { offices [17] }\end{array}$ & 3.87 & 3.42 \\
\hline B27 & Increasing government accountability to citizens [4], [44] & 3.50 & 3.05 \\
\hline & Average & 3.86 & 3.19 \\
\hline & & \\
\hline
\end{tabular}

